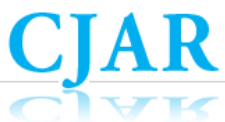

Canadian Journal of Action Research

Volume 21, Issue 1, 2020, pages 10-26

\title{
WHY ARE THINGS AS THEY ARE? ACTION RESEARCH AND THE TRANSFORMATION OF WORK AND EDUCATION IN THE NEOLIBERAL AGE
}

\author{
E. Wayne Ross \\ University of British Columbia
}

\begin{abstract}
What we understand about the world is determined by what the world is, who we are, and how we conduct our inquiries. Action research privileges the question "why are things as they are?" This article explores how neoliberalism, with its key principle that competition is the defining characteristic of human relations, reshapes our work as educators and researchers, and discusses how action research can help us not only better understand our world, but also resist the deleterious effects of neoliberalism on our work and workplaces.
\end{abstract}

KEY WoRDS: Critical participatory action research; Global educational reform movement; Higher Education; Neoliberalism; Public education; Workplace transformation

\section{INTRODUCTION}

It is almost impossible to avoid quantified metrics in in our everyday life, from the numbers of followers or likes on social media, to tracking workouts, sleep patterns, screen time and steps, to collecting data on the activities of our infant children to make inferences about behaviour and health. Various aspects of data fetishism in everyday life have become normalized as self-tracking devices and social media entice us to feel a sense of satisfaction and achievement based on numerical data.

Quantitative metrics have also transformed the conditions of our work, particularly in public institutions which have experienced reduced government funding and have shifted toward corporate models of management. Spooner and McNinch (2018) argue that we live in an age in which value is equated with accountancy and where we are "increasingly governed by and through numbers, incentives, de-incentives and competitive benchmarking" (p. xxiv). This kind of bureaucratic outcomes-based accountability or managerialism is now the accepted norm in schools, universities and other public 
institutions, and it has a direct effect on the content of our work and the ways in which we conceptualize and carry out our work as teachers, professors, researchers, and scholars.

For example, in schools, we see students, teachers and administrators held accountable to government agencies for demonstrating academic success on a small and static set of indicators of individual student performance. Schools have a common set of expectations and standards, with clear cut-offs to indicate success or failure, and there are consequences at the individual and school level for failure. The deleterious effects of bureaucratic accountability include reducing teaching to testing, standardized curriculum, learning activities that mimic test items, de-professionalization of teachers, emphasis on learning for marks, valuing achievement over ability and effort, and loss of student control and choice (Mathison \& Ross, 2008).

The effects of managerialism in higher education have transformed the work of and social relations among academics as accountancy, control and efficiency have displaced moral purpose and the public good as institutional drivers.

As managerialism creeps into every facet of the academy, we risk conceding what little autonomy remains to collaboratively and collegially manage ourselves, and to freely research, critique, act, and organize with the wider communities and movements that characterize our location. The seductive and insidious nature of management is such that it holds the potential to disorient people, causing them to lose sight of universities' more laudable missions-as typically encapsulated in their mottos-and to focus rather on depersonalized spreadsheets and the false idol of a narrowly defined accountability. Audit culture's tentacles diminish disciplinary autonomy and local authority, bypassing criteria documents and performance review bodies. Ultimately at stake is the very notion of what can be considered knowledge itself. (Spooner \& McNinch, p. xxiv)

Managerialism or New Public Management is an approach to running public service institutions and agencies based upon business principles, focusing on efficiency and the market. It has been described as the "the organizational form of neo-liberalism" (Lynch, 2014). As Spooner and McNinch make clear, the normalization of neoliberal management practices as common-sensical or pragmatic masks the fact that it is an ideological project that has "infiltrated and reorganized knowledge production in academic institutions by closely aligning them with the 'value-chain' and commercialization of knowledge" (Jordan \& Kapoor, 2016, p. 134).

Action research and related methodologies have been increasingly affected and appropriated by neoliberalism, and in particular by managerialism in public institutions. Jordan and Kapoor (2016) argue that the ascendency of neoliberalism has "produced homogenizing and assimilationist tendencies in social and educational research that have profoundly affected the character" (p. 135) of action research, particularly participatory action research. Jordan and Kapoor (2016) argue that these tendencies have led to professionalization that continues to reconstitute action research as a scientific/technical 
endeavour divorced from its antecedents of democracy as well as radical and emancipatory politics. They also argue that participatory approaches to research are being co-opted by academic researchers, the professions and managerial consultants (e.g. program evaluators) as a means to enhance forms of social regulation that support and sustain the social relations of neoliberal accumulation and the coloniality of power (Fanon, 2005; Quijano, 2000). As a result, participatory action research is now in danger of being mainstreamed within the academy as 'participatory academic research' (Kapoor, 2009). As a consequence, contemporary practitioners of action research must engage in a sustained re-evaluation of its underlying principles, practices, organization and theory (Jordan \& Kapoor, 2016).

Against this background, this article aims to explore the origin and nature of neoliberalism and its impact on education and other public services. This article aims to explore the following questions: Are neoliberalism and education compatible? How can we resist neoliberalism in our work and workplaces? What special role can/does action research play in resistance to neoliberal managerialism?

\section{THIS IS WATER / THIS IS NEOLIBERALISM}

There are these two young fish swimming along, and they happen to meet an older fish swimming the other way, who nods at them and says, "Morning, boys. How's the water?" And the two young fish swim on for a bit, and then eventually one of them looks over at the other and goes, "What the hell is water?"

David Foster Wallace (2005)

Neoliberalism is the water we are swimming in. It is the medium we live in and we are generally not conscious of it. We should be conscious of it because neoliberalism is the ideology that is the root of some of our most important problems, such as environmental disaster, financial crises, the rising tide of inequality, and the destruction of public education that serves public interests. Neoliberalism is the most recent evolutionary form of capitalism. Its key principle is that competition is the defining characteristic of human relations (Monbiot, 2016); it is the intensification of competition, individuality, and power.

For capitalism to maintain its grip, it needs to drive a mass of the population into poverty but also to educate the population to believe that poverty is their own individual problem rather than a function of this miserable economic system. (Parker, 2017, p. 87)

Contemporary schools and universities are defined by bureaucratic outcomes-based accountability, audit culture, performance-based funding, surveillance technologies, automation, bullying, mobbing, casualization, precarity, intensification, fragmentation, segmentation, gentrification of criticism and dissent, all of which create (academic) stress and feed into attacks on academic freedom, free speech, and faculty solidarity, as well as the creation of the all-administrative university (Ginsberg, 2011). To understand the nature of schools and universities, to navigate their waters, and to re-imagine the 
ecosystem of learning, teaching, and researching, we have to understand how neoliberalism defines our institutions, work, goals, and our very lives.

The term neoliberalism emerged in the middle of the twentieth century through the work of Austrian economists Ludwig von Mises (1944) and Frederick Hayek (1944). In 1947, a network of transatlantic intellectuals and economists formed the Mont Pelerin Society to spread the ideology of neoliberalism (Jones, 2014), "as a result, the neoliberal doctrine, a reformed version of liberalism, was created to establish unfettered and expanded markets to harness individual choice" (Maisuria \& Helms, 2020, p. 7).

When the Mont Pelerin Society was formed, the dominant economic framework in the postwar world was Keynesianism. Keynesian economics advocated increased government spending and lower taxes for working people to stimulate demand. As a result, economic policies in this era focused on full employment and relief of poverty. Tax rates on the rich were high and governments developed new public services (e.g., expansion of public higher education) and social and economic safety nets. It was not until the economic recession of 1970s that neoliberalism gained a strong foothold in government policy and practice.

The neoliberal turn in economic and social policies was facilitated by the movement's tremendously wealthy backers who funded a series of think tanks (e.g., American Enterprise Institute, Cato Institute, Heritage Foundation, and in Canada, Fraser Institute and Institut économique de Montréal). It was also facilitated by academic positions, university departments and programs that refined and promoted the ideology with such success that its fundamental principles are now taken for granted. Margaret Thatcher in the UK and Ronald Reagan in the USA were the prototypical neoliberal political leaders with agendas that included massive tax cuts for the wealthy, attacks on trade unions, deregulation of industry, outsourcing, and privatization of public services.

Neoliberal policies are imposed internationally, without democratic consent, through the International Monetary Fund, the World Bank, the Maastricht treaty and the World Trade Organisation. Most remarkable is its adoption among parties that once belonged to the left: Labour in the United Kingdom, the Democrats in the United States, and the New Democrats in Canada, for example.

In Canada, neoliberalism was fully embodied in the policies and practices of Stephen Harper's federal government (Gutstein, 2014), but is also the defining ideology of the current Liberal government (Cole, 2016) as well as in the long reign of the British Columbia Liberals (Ross, 2010) among other provincial governments. There are several examples of neoliberalism overwhelming public interests in $\mathrm{BC}$ :

- In 2002, the BC Liberal government legislated a three-year contract on teachers that stripped their contract of class size, teacher workload, composition and specialist teacher ratios. It also forbade them from negotiating those issues in future contracts. This legislation resulted in drastic cuts to teaching positions and many schools were 
also closed. In 2016, the legislation was declared unconstitutional by the Supreme Court of Canada.

- BC Hydro: Since 2007, BC government policy transformed the province's electricity system from publicly owned to one operated in the interests of private energy developers and multinational energy corporations.

- BC Rail: Sold ("leased" for 99 years) to CN in 2004, which also produced a scandal known as "Railgate."

- BC Ferries: A Crown Corporation until 2003 when government privatized it with the aim of "improving services". The result has been fee hikes and reduced sailings rather than being operated as part of the provincial highway system or as a public service.

- Trans Mountain Pipeline: The intermingling of government and corporate interests in profit making came up against local community interests in the environment and Indigenous rights, with an as of yet uncertain outcome.

Public services in general, and public education in particular, are key targets of neoliberal social and economic policy makers and governments, as Maisuria and Helms (2020) point out,

A report disseminated amongst the neoliberal reformers in the 1970s highlighted the need to bring 'value-oriented intellectuals' of left-wing persuasion and 'journalists who favour "the cause of humanity"' under control (Sklar, 1980, p. 40). Especially, progressive educators and those working within the media were seen as a threat to certain individuals working within the 'world of high finance', and thus needed to be made more 'governable and more able to service capital' (Davies \& Bansel, 2007, p. 250). Neoliberal policies introduced in education from the 1980s began the attempted wholesale destruction of educators with left-wing, progressive, and liberal commitments, and education systems based on these values (Giroux, 2014; Maisuria, 2015). (p. 7)

Commenting on Hayek's original vision of neoliberalism, Jones (2014) concluded, "it is hard to think of another utopia to have been as fully realised" (p. 82).

\section{Are Neoliberalism and Education Compatible?}

Can we have education under the neoliberal yoke? In short, the answer is no, education and neoliberalism are not compatible. This incompatibility stems from the antipathetic relationship between capitalism and democracy, but let me elaborate on education and neoliberalism. First, it matters what is meant by the term education. Of course, the giving and receiving of systematic instruction in schools, universities and informal learning spaces is a key means by which the politics of truth are officially defined. Public schools and universities have been and continue to be profoundly conversing in nature, illusion factories whose primary aim is reproduction of the existing social order, where ruling ideas exist to be memorized, regurgitated, internalized and lived by (e.g., Delgado \& Ross, 2016). 
In education, neoliberalism has manifested in what Finnish educator Pasi Sahlberg (2012) has dubbed the Global Education Reform Movement (GERM), which includes: increased competition between educational institutions; commodification of education that positions students and parents as consumers in an education marketplace; and powerful systems of accountability tied to performance standards for students as well as practices such as "new public management" or the what has been called the "businessification" of education (Hill, 2006).

This corporate/state regulation and administration of education, is a move that enables "systems of unaccountable power" (Lydon, 2017) to make self-interested decisions ostensibly on behalf of the public when, in fact, most members of the public have no meaningful say in what or how decisions are made or in what can count as legitimate knowledge (Gilens \& Page, 2014). This, of course, is purposeful and involves the coordinated control of such processes as goal setting, curriculum development, testing, research funding and activities, student and faculty evaluation.

Neoliberalism, via GERM, marketizes public education systems, opening the door for extraction of profits from a public service through various schemes such as: for-profit management systems; off-shore schools and universities; selling seats in schools and universities on the international market; massive regimes of standardized testing that are a boon to publishers selling the tests and the textbooks; and using public money to support private education, etc. (Kuehn, Mathison, Ross, 2018; Ross, 2014).

It is helpful to contrast a market-based business plan with an educational plan for setting and enacting policy. A market-based business plan moves us away from The Commons the idea that wealth belongs to everyone, and community resources must be protected and managed for the good of all. In contrast, an educational plan supports and protects the role of public education to provide an education to all within their communities.

Market-based Business Plan

- Make income over costs

- Seek students from outside district/province/country who will bring income

- Competitive

- Create resources to sell

- Offer incentives
Educational Plan

- Provide services based on student needs, not fees

- Serve the students in the community

- Cooperative

- Create resources free for all

- Supports based on needs

(Kuehn, Mathison, \& Ross, 2018)

Privatization is a threat to the principle of public education as a public interest, and is an outgrowth of neoliberalism, a form of minimal state intervention plus free market principles evident in many nations and in many sectors since the 1980s. Privatization fundamentally changes the nature of relationships within education and is a value laden 
policy strategy (Schuetze, Kuehn, Davidson-Harden, Schurgurensky \& Weber, 2011; Kuehn, Mathison \& Ross, 2018).

One of the key ways in which neoliberalism is manifest is by the privatization of public goods and services, and privatization itself has multiple manifestations. A distinction is often made between the privatization of and in public education. When the design, management and delivery of public education is opened to private, for-profit entities, this constitutes the privatization of public education. Examples include public-private partnerships, private schools funded by government (whether elite, religious or specialized, such as distributed learning for special needs children) and charter schools. When ideas, strategies and techniques are imported from the private sector to public education, the result is privatization in public education. In essence, schools and universities are expected to act like competitive, profit-driven businesses. Examples include school choice within public school systems through the creation of boutique programs, school leadership as business management, merit pay, prioritizing efficiency over effectiveness, and the use of outcome measures like student test scores as best indicators of quality.

The University of British Columbia's Vantage College is a prime example of the privatization of public higher education. UBC sells seats to international students at seven times the rate it charges Canadian students, and has one of the highest percentages of international students among universities worldwide. There are many international students who do not qualify for admission to UBC, but who can afford to pay the sky-high UBC tuition. UBC created Vantage College for these students. It is a program that exclusively accepts international students who are unable to meet UBC's requirements but who can afford UBC international tuition plus and an additional $\$ 6000$ fee for the 11 month program (Knuibutat, 2015). ${ }^{1}$

Because BC public schools have been inadequately funded for many years, the need to raise money at the school or district level to offset budget short-falls leads to the most insidious form of privatization. Revenue from K-12 international public school students has increased from $\$ 55$ million to $\$ 242$ million since 2002, "but not all school districts are equally positioned to solicit and cater to potential international students and, as a consequence, the benefits are disproportionately distributed. In general, richer, larger districts get richer" (Kuehn, Mathison \& Ross, 2018, p. 9).

Slowly, gradually and subtly many schools, teachers and parents have come to see the need to raise money as a normal part of funding education. Student fees, fundraisers, targeted business patronage, school district business development offices, branding to students, and seeking philanthropic sponsors and donors. All

\footnotetext{
1 As UBC collects higher and higher tuition and fees from international students, it fails to provide adequate bursaries for low-income Canadian students. Many of my own students are forced go into debt to pay for their B.Ed., and UBC counsels them into its partnership with a local bank for access to a line of credit that is aligned with estimates of future earning power based upon their field of study, e.g., students in pharmacy qualify for higher debt levels than students in education.
} 
have become part of the landscape of schools. In BC, a key form of revenue generation is the encouragement to enrol international students, which generates substantial revenue at the school/district level (about $\$ 13,500 /$ student for the now approximately 20,000 international students in BC schools). (Kuehn, Mathison \& Ross, 2018, p. 8)

When public education is forced into the economic marketplace, the marketplace of ideas becomes restricted. School curricula reflect 'official knowledge', where themes are defined by a right-wing cultural hegemony, including control of textbook content and the increased role of private business in schools (Apple, 1993; Ross \& Vinson, 2013). Meanwhile, universities are driven by the needs and interests of corporate capitalism, asking questions like "How do we educate more workers to do these jobs?" Their answer, according to Shannon and Shannon (2013), is

to provide a curriculum that normalizes the "is" of "the world in which we're living" through a deterministic view of the possibilities of ICT technology and the abandonment of the democratic project of equality (and justice). The expected outcome of that curriculum is adaptation by the 95 percent to contribute small data and resources that will flow to the 5 percent, who will craft the future from these data in order to sell it back as innovation in various forms of commodities, services and rules. The assessment of this outcome is located in the literacy articulated in the $21^{\text {st }}$ century themes: each individual polices him or herself continuously in order to "make appropriate personal economic choices," defer power to authority, and understand "preventive physical and mental health measures, including proper diet, nutrition, exercise, risk avoidance, and stress reduction." The goal of it all is to increase the speed of wealth accumulation through current iterations of a marketbased world in which we are living. (p. 77)

What exists here is an unambiguous, power-laden connection between the regulation of knowledge on the one hand and the (de)regulation of the economy on the other, a joint effort by the politically, culturally, and economically powerful (nominally on behalf of the public) designed to stifle popular democracy while simultaneously enhancing the profits of multinational corporations and the ultra-rich. It is a reproductive and circular system, a power-knowledge-economics regime in which the financial gains of a few are reinforced by what can count as knowledge, and in which what can count as knowledge is determined so as to feed the financial greed of corporations.

\section{Resisting Neoliberalism, Transforming OUR Work (AND WorkPlaces) ${ }^{2}$}

The first step in resisting neoliberalism is realizing that we are not 'all in this together', that is, neoliberalism benefits the few at the expense of the many (Ross \& Gibson, 2007). The corporate mass media would have us adopt the mantra that what is good for the corporate capitalist class is good for the rest of us-thus we have the 'logic' of 'efficiency' or 'cost containment' in education prized over the educational well-being of the public.

\footnotetext{
${ }^{2}$ Parts of this section appeared in different form in Petrina and Ross (2014) and Ross (2018).
} 
Public debates in the corporate media about education (and other social goods) are framed in ways that serve the interests of elites. For example, in BC, free market neoliberals in think tanks such as the Fraser Institute and in the dominant media outlets have been successful in framing discussions on education in terms of accountability, efficiency, and market competition. A frame is the central narrative - the organizer - for making sense of particular issues or problems (e.g., problem definition, origin, responsible parties) and solutions (e.g., policy). The frame is presented as common sense, thus the assumptions underlying the frame are typically unquestioned or at least under-analyzed.

It is imperative that educators challenge the dominant neoliberal frames that would define education as just another commodity from which profits are to be extracted. Examples of resistance include individual teachers and professors working to reframe curricula in their classrooms (e.g., Marmol, 2015; Ross \& Queen, 2010; Ramsey, 2018) as well as collective resistance of students, educators, parents and community activists working together on a broad array of fronts, such as the Rouge Forum and the Post-Crash Economics Society (Gibson, Queen, Ross, \& Vinson, 2009; Delgado \& Ross, 2016).

Efforts to reframe the neoliberal narratives of higher education have been underway for decades. In her review of Nelson and Watts' (2004) book, Office Hours: Activism and Change in the Academy, Michelle Fine (2005) brings critical higher education to a three-way crossroads. Characterizing Office Hours as an immensely productive synopsis of second and third generation critical university studies, Fine describes this crossroads for a third generation:

First, we need to document the elaborate circulations of money, power, networks, access, censorship, and surveillance that have metastasized between the academy and prisons, the military, government, and corporate interests.... But we need more.... Second, while Office Hours delineates the intergenerational and the discipline-specific implications of the corporate academy, we need more finegrained analyses of its fallout for faculty of color, lesbian and gay faculty, Muslim faculty, and activist faculty. All of these groups are newer to the academy and better represented among the nontenured ranks. While the assault on higher education affects us all, a movement for academic justice must interrogate how the wreckage of proletarianization distributes along the interior fault lines built into the academy. Third, the struggles of higher education need to be linked to those of our colleagues in K-12 public education. Deep in the devastation wrought in elementary and secondary education by some of the same forces of the political economy lie educators with knowledge about oppressive consequences and about organizing. (p. 63)

In this quotation, the crossroads is brought to stark relief. Of course, after more than a century of first and second-generation critical university studies, where defending academic freedom in the culture wars could mean the difference between liberty or prison, promoted or sacked, unencumbered or investigated, or life or death, crossroads induce 
mixed feelings. The dreadful threats to paid intellectual work that Fine so clearly articulates are ever present, deflating, and demoralizing.

Audit culture and new public management imperil action research, particularly critical participatory action research that has an interest in emancipating people from irrationality, unsustainability and injustice (Kemmis, McTaggart \& Nixon, 2014). However, it is important to understand that these are threats not just to action research but the larger project of critical higher education.

\section{How Can Action Research Contribute to Transforming Neoliberalism?}

Neoliberalism is a direct attack on democratic ideas and practices in general (Ross \& Gibson, 2007) and on action research in particular (Villacañas de Castro, 2019). Action research has the potential to be a powerful force for democracy in society and within the workplace. Villacañas de Castro argues that Deweyan democracy and action research are symbiotic. Dewey's pragmatist epistemology rejects the false dualism of science and practice (Dewey, 1916).

... just as education should not forgo the basic elements of social interactiondeliberation, a social purpose, and a practical dimension-if it was to avoid turning itself into a meaningless and repetitive activity, scientific inquiry needed both to arise and return to the contexts, practices, and situations of the daily life. (Villacañas de Castro, 2019, p. 30).

Like pragmatism, action research rejects a positivist conception of knowledge and can be understood as a form of inquiry oriented toward improving social practices in the original contexts where they take place, thus rejecting the social divisions of labour and the theory/practice divide imposed by neoliberal managerialism. Indeed, as Villacañas de Castro argues, action is well suited to guide institutional transformation aimed at strengthening and improving democratic life in workplaces and society. Action research can serve as a democratic alternative to neoliberal models of public management that have (mis)shaped institutions over the past half century, and can reverse the effects of managerialism.

Critical participatory action research provides a unique framework for understanding and transforming our workplaces, including resisting the deleterious effects of neoliberalism on educational contexts. Methodologically, action research privileges participants and the particularities of situations, as such it provides affordances lacking in other more traditional positivistic or apolitical research approaches.

Kemmis, McTaggart and Nixon (2014) argue 'insiders' have unique advantages "when it comes to doing research in their own sites and investigating practices that hold their work and lives together in those sites-the practices that are enmeshed with those sites" (p. 5). These advantages include:

- understanding from "within" the practices and conventions that inform and orient them; 
- creating conditions for practitioners to share a language and participate in conversations and debates of those whose action constitutes the practice being investigated as well as creating the forms of action and interaction in which the practice is conducted;

- creation of communities of practice "through which the practice is conducted, both in the relationships among different participants in a particular site and in the relationships among people who are collectively responsible for the practice"; and

- individually and collectively working to transform the conduct and consequences of their practice to meet the needs of changing times and circumstances by confronting and overcoming "untoward consequences", such as practices that are irrational, unsustainable and unjust. (Kemmis, McTaggart \& Nixon, 2014, p. 5-6)

It is the last of these characteristics that distinguishes critical participatory action research, it is what makes it "critical" or at least potentially so.

What we understand about the world is determined by what the world is, who we are, and how we conduct our inquiries. Action research privileges the question "why are things as they are?" Things change. Everything in the world is changing and interacting. When studying social issues or practices, action researchers should begin by challenging the common sense idea of a social issue or practice as a "thing" and consider the processes and relationships that make up what we think of as a social issue or practice, which includes its history and possible futures. Inquiries into social issues and practices help us understand how things change and also contribute to change, which is a defining characteristic of action research.

In understanding social issues and practices as well as how things change, it helps to 'abstract', or start with, 'concrete reality', and break it down. Abstraction is like using camera lenses with different focal lengths: a zoom lens to bring a distant object into focus (what is the history of this?) or using a wide-angle lens to capture more of a scene (what is the social context of the issue or practice now?)

This dialectical approach raises important questions: where does one start and what does one look for? The traditional approach to inquiry starts with small parts and attempts to establish connections with other parts leading to an understanding of the larger whole. Beginning with the whole, the system, or as much as we understand of it, and then inquiring into the part or parts of it to see how each fits and functions can lead to a fuller understanding of the whole. Analysis of present conditions is necessary, but insufficient. The problem is that reality is more than appearances, and focusing only on appearances, the face value of evidence from our immediate surroundings, can be misleading.

How do we think adequately about social issues and practices, giving issues the attention and weight they deserve, without distorting them? We can expand our notion of a social issue or practice (or anything for that matter) to include, as aspects of what it is, both the process by which the issue has come to life and the broader interactive context in which it is found. In this way, the study of a social issue or practice involves the study of its history 
(i.e., its preconditions and connections to the past) and the encompassing system. Remembering that "things change" provokes us to move beyond analyzing current conditions and historicizing social issues, to project probable or possible futures. In other words, our inquiry leads to the creation of visions of possible futures.

This process of inquiry, then, changes the way we think about a social issue in the here and now (change moves in spirals, not circles), in that we can look for preconditions of a future in the present and use them to develop political strategies (i.e., organize for change). So, what can we do collectively and in the spirit of critical participatory action research?

1. We need to act on the economic imperative of faculty alliances with a radically charged student movement in response to a decimated job market, incapacitating debt burdens, and contraction of the professoriate.

2. We need to act on the ethical imperative of alliances with class, environmental, race and other identity grounded grassroots social movements.

3. We need to act on the legal imperative of alliances across the left and right in the throes of aggressive suppression of academic freedom downplayed by administrators exaggerating a civility crisis and exercising investigative powers through new respectful workplace policies.

4. We need to act on the political imperative of making critical university studies by remaking the critical and the university (Petrina \& Ross, 2014).

What is it about the adjective, the incitement, 'critical' that distinguishes critical higher education? What is it that makes critique - in its contemporary form first deployed by Kant in 1781 - so enduring and threatening or, conversely, time-bound, steamless, and unable to boil up emotion over into alliances and down to substantive change? In the face of acute and sustained critique of critique, it is inadequate to defend or make critical higher education by trotting out standard fare, such as:

"Critical" indicates the new work's oppositional stance, similar to approaches like critical legal studies, critical race studies, critical development studies, critical food studies, and so on, that focuses on the ways in which current practices serve power or wealth and contribute to injustice or inequality rather than social hope. (Williams, 2012)

If this is what the critical of critical higher education has been, given trends and compromises in the civility crisis (Petrina, 2012; Petrina \& Ross, 2014), it has proven fairly ineffective under its own roof, and it would be futile or hypocritical in the big houses, the demos, nomos, oikos. If the critical of critical higher education is simply about the self, the autos, the powerful, the critic, two experts in tow, then yes, much has been and can be learned. This effectively removes us 230 years to limits of knowledge and the first critique.

Critical higher education is nonetheless a necessary check on three disciplines: educational administration, higher education, and leadership. It seems critical higher education lost sight of these goal as alarming winds of change swept across the university system during 
the 2000s (Ginsberg, 2011). Perhaps in this crisis of administration, critical education was left as a bystander. On one level, administration is defined as decision-making, and we have all likely experienced administrators who could not make a decision and would not move on while at the same time witnessed great administrators removed, apparently because they could and did make decisions. Administrators who cannot administrate or make decisions for the common good beg the question, in what way or "why are they leaders?" (Smyth, 2018). The other dimension, as Thayer (1980) suggests, is that administrators without courage might as well admit: "I must accept whatever my advisers tell me" (p. 6).

The days of "service" through higher education are closing by yielding to "engagement," or more regrettably the trilogy of 'research, teaching and service' in the university has been sequeled by 'scholarship, facilitation, and engagement.' This is regrettable in that a longstanding system, which included full time faculty in a tenure track subsystem, is yielding to a very different political economy of higher education. In this economy, how do we account for critical education? What might critical facilitation or engagement mean or do?

As research, teaching and service yield to scholarship, facilitation and engagement, the semantics of the critical - the common ground of critics and their critics - in war and peace is itself critical. Otherwise we might just as well displace the critical of critical higher education with cultural or collateral, as that seems to be what is transpiring.

Latour (2004) begins one of the most trenchant critiques of critique in the last thirty years by asking: "Should we be at war, too, we, the scholars, the intellectuals?" (p. 225). An easy answer is enough is enough, qualified by the next simple question: Can we be at peace? What are our options?

\section{REFERENCES}

Apple, M. W. (1993). Official knowledge: Democratic education in a conservative age. New York, NY: Routledge.

Cole, J. (2016). Neoliberalism as historical narrative: Some reflections. Our Schools / Our Selves, 26(1), 41-58. Retrieved from https://www.policyalternatives.ca/sites /default/files/uploads/publications/National\%200ffice/2016/10/0S125_final_Col e.pdf

Davies, B., \& Bansel, P. (2007). Neoliberalism and education. International Journal of Qualitative Studies in Education, 20(3), pp. 247-259.

Delgado, S., \& Ross, E. W. (2016). Students in revolt: The pedagogical potential of student collective action in the age of the corporate university. Knowledge Cultures, 4(6), 141-158.

Dewey, J. (1916). Democracy and education. New York, NY: Free Press. 
Fanon, F. (2005). The wretched of the earth. New York, NY: Grove. (Originally published in 1963)

Fine, F. (2005). Book Review. [Review of the book Office hours: Activism and change in the academy, by C. Nelson]. Academe, 91, pp. 61-63.

Gibson, R., Queen, G., Ross, E. W., \& Vinson, K. D. (2009) The Rouge Forum. In D. Hill (Ed.), Contesting neoliberal education: Public resistance and collective advance (pp. 110136). New York: Routledge.

Gilens M., \& Page, B. I. (2014). Testing theories of American politics: Elites, interest groups, and average citizens. Perspectives on Politics, 12(3). 564-581. Retrieved from https://scholar.princeton.edu/sites/default/files/mgilens/files/gilens_and_page_20 14_-testing_theories_of_american_politics.doc.pdf

Giroux, H. A. (2016). Radical politics in the age of American authoritarianism: Connecting the dots. Truthout. Retrieved from https://truthout.org/articles/radical-politics-inthe-age-of-american-authoritarianism-connecting-the-dots/

Ginsberg, B. (2011). The fall of the faculty: The rise of the all-administrative university and why it matters. Oxford: Oxford University Press.

Gutstein, D. (2014). Harperism: How Stephen Harper and his think tank colleagues have transformed Canada. Toronto, ON: Lorimer.

Hayek, F. A. (1944). The Road to serfdom. London, UK: Routledge.

Hill, D. (2006). Educational perversions and global neoliberalism. In E. W. Ross \& R. Gibson, Neoliberalism and education reform (pp. 107-144). Cresskill, NJ: Hampton Press.

Jones, D. S. (2014). Masters of the universe: Hayek, Friedman, and the birth of neoliberal politics. Princeton, NJ: Princeton University Press.

Jordan, S., \& Kapoor, D. (2016). Re-politizing participatory action research: Unmasking neoliberalism and illusions of participation. Educational Action Research, 24(1), 134149.

Kapoor, D. (2009). Participatory Academic Research (Par) and People's Participatory Action Research (PAR): Research, politicisation, and subaltern social movements in India. In D. Kapoor and S. Jordan (Eds.), Education, participatory action research, and social change (pp. 29-44). New York, NY: Palgrave Macmillan.

Kemmis, S., McTaggart, R., \& Nixon, R. (2014). The action research planner: Doing critical participatory action research. New York, NY: Springer. 
Knibutat, S. (2015, January 14). UBC's Vantage College draws criticism. The Varsity. Retrieved from https://thevarsity.ca/2015/01/14/ubcs-vantage-college-drawscriticism/

Kuehn, L., Mathison, S., \& Ross, E. W. (2018, June 5). The many faces of privatization. Institute for Public Education/British Columbia, Occasional Paper No. 1. Vancouver, BC: Institute for Public Education/BC. Retrieved from https://instituteforpub liceducation.org/wp-content/uploads/2018/06/Many-Faces-of-PrivatizationIPEBC-Occasional-Paper-1.pdf

Latour, B. (2004). Why has critique run out of steam? Critical Inquiry, 30, 225-248.

Lydon, C. (2017, June 2). Noam Chomsky: Neoliberalism is destroying our democracy. The Nation. Retrieved from https://www.thenation.com/article/noam-chomskyneoliberalism-destroying-democracy/

Lynch, K. (2014, September 16). New managerialism' in education: The organisational form of neoliberalism. Open Democracy. Retrieved from https://www.open democracy.net/en/new-managerialism-in-education-organisational-form-ofneoliberalism/

Maisuria, A. (2015). Margaret Thatcher's legacy, academisation and the demise of state education. British Education Research Association (BERA) Blog. Retrieved from https://www.bera.ac.uk/blog/thatcher-the-state-school-snatcher

Maisuria, A., \& Helms, S. (2020). Life for the academic in the neoliberal university. Abingdon, UK: Routledge.

Marmol, E. (2015). The corporate university: An e-interview by Emile Marmol with Dave Hill, Alpesh Maisuria, Anthony Nocella and Michael Parenti. Critical Education, 6(19). Retrieved from https://ices.library.ubc.ca/index.php/criticaled/article/view/ 185102

Mathison, S., \& Ross, E. W. (2008). The nature and limits of standards-based reform and assessment. New York, NY: Teachers College Press.

Monbiot, G., (2016, April 15). Neoliberalism - the ideology at the root of all our problems. The Guardian. Retrieved from https://www.theguardian.com/books/ 2016/apr/15/neoliberalism-ideology-problem-george-monbiot

Nelson, C., \& Watt, S. (2005). Office hours: Activism and change in the academy. New York: Routledge.

Parker, I (2017). Revolutionary keywords for a new left. Washington, DC: Zero Books.

Petrina, S. (2012). The New critiquette and old scholactivism: A petit critique of academic manners, managers, matters, and freedom. Workplace: A Journal for Academic Labor, 
20, 17-63. Retrieved from https://ices.library.ubc.ca/index.php/work place/article/view/182503

Petrina, S. \& Ross, E. W. (2014). Critical university studies: Workplace, milestones, crossroads, respect, truth. Workplace: A Journal for Academic Labor, 23, 62-72. Retrieved from https://ices.library.ubc.ca/index.php/workplace/article /view/184777

Quijano, A. (2000). Coloniality of power and eurocentrism in Latin America. International Sociology, 15(2), 215-232.

Ramsey, J. G. (Ed.). (2018). Scholactivism. Cultural Logic, 22. Retrieved from https://ojs.library.ubc.ca/index.php/clogic/issue/view/182832

Ross, E. W. (2010). Resisting the common-nonsense of neoliberalism: A Report from British Columbia. Workplace: A Journal for Academic Labor, 17. Retrieved from https://ices.library.ubc.ca/index.php/workplace/article/view/182326

Ross, E. W. (2014, June 28). Private education funding is undemocratic. Times Colonist. Retrieved from https://www.timescolonist.com/opinion/op-ed/comment-privateeducation-funding-is-undemocratic-1.1185002

Ross, E. W. (2018). Humanizing critical pedagogy: What kind of teachers? What kind of citizenship? What kind of future? Review of Education, Pedagogy, and Cultural Studies, 40(5), 371-389.

Ross, E. W., \& Gibson, R. (Eds.). (2007). Neoliberalism and education reform. Cresskill, NJ: Hampton Press.

Ross, E. W., \& Queen, G. (2010). Globalization, class, and the social studies curriculum. In D. Kelsh, D. Hill \& S. Macrine (Eds.), Class in education: Knowledge, pedagogy, subjectivity (pp. 153-174). New York: Routledge.

Ross, E. W., \& Vinson, K. D. (2013). Resisting neoliberal education reform: Insurrectionist pedagogies and the pursuit of dangerous citizenship. Cultural Logic, 20. Retrieved from https://ojs.library.ubc.ca/index.php/clogic/article/view/190890

Sahlberg, P. (2012). Global education reform movement is here! Blog by Pasi Sahlberg. Retrieved from https://pasisahlberg.com/global-educational-reform-movement-ishere/

Schuetze, H. G., Kuehn, L., Davidson-Harden, A., Schurgurensky, D., \& Weber, N. (2011). Globalization, neoliberalism and schools: The Canadian story. In R. V. Heertum, C. A. Torres, \& L. Olmos (Eds.), Educating the global citizen in the shadow of neoliberalism: Thirty years of educational reform in North America. Oak Park, IL: Bentham Science Publishers 
Shannon, T. P., \& Shannon, P. (2013). Learning to be fast capitalists on a flat world. Cultural Logic, 20. Retrieved from https://ojs.library.ubc.ca/index.php/clogic /article/view/190892

Sklar, H. (1980). Trilateralism: The Trilateral Commission and elite planning for world management. Montreal, Canada: Black Rose Books.

Smyth, J. (2018). The toxic university: Zombie leadership, academic rock stars and neoliberal ideology. London, UK: Palgrave Macmillan.

Spooner, M., \& McNinch, J. (2018). Dissident knowledge in higher education. Regina, SK: University of Regina Press.

Thayer, F. (1980, January-February). "Response to Vicker's comments in the Nov/Dec '79 Issue. Dialogue 2, 4-6.

Villacañas de Castro, L. S. (2019). Deweyan democracy, neoliberalism and action research. Studies in Philosophy and Education, 39, 19-36. https://doi.org/10.1007/s11217019-09664-1

von Mises. L. (1944). Bureaucracy. New Haven, CT: Yale University Press.

Wallace, D. F. (2005). This is water. Retrieved from https://theartian.com/2015 /02/24/this-is-water-david-foster-wallace/

Williams, J. J. (2012, February 19). Deconstructing academe: The birth of critical university studies," Chronicle of Higher Education. Retrieved from https://chronicle.com/article/An-EmergingField-Deconstructs/130791/

\section{BIOGRAPHICAL NOTE:}

E. Wayne Ross is a professor in the Department of Curriculum and Pedagogy and codirector of the Institute for Critical Education Studies at The University of British Columbia in Vancouver, Canada. He teaches and writes about the politics of curriculum, critical pedagogy, social studies education, and academic labor. He is the editor the three openaccess journals: Critical Education, Cultural Logic, and Workplace: A Journal for Academic Labor. His most recent book is Rethinking Social Studies: Critical Pedagogy in Pursuit of Dangerous Citizenship (Information Age Publishing, 2017). 